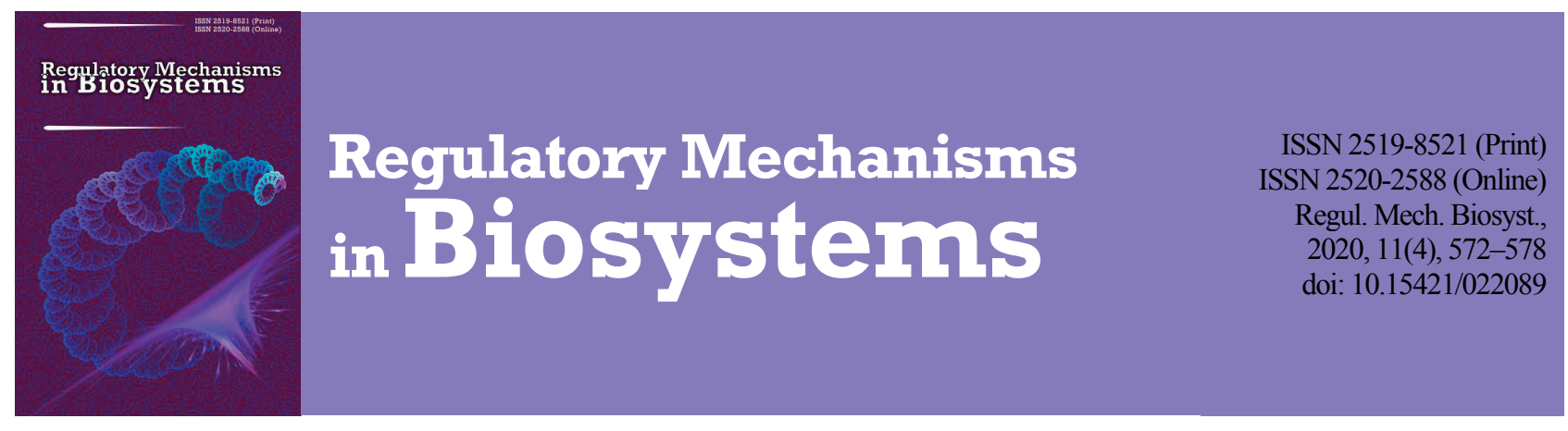

\title{
Antagonistic activity of strains of lactic acid bacteria isolated from Carpathian cheese
}

\author{
L. Y. Musiy, O. Y. Tsisaryk, I. M. Slyvka, I. I. Kushnir \\ Stepan Gzhytskyi National University of Veterinary Medicine and Biotechnologies (Lviv), Lviv, Ukraine
}

Article info

Received 04.10.2020

Received in revised form 15.11.2020

Accepted 20.11.2020

\author{
Musiy, L. Y., Tsisaryk, O. Y., Slyvka, I. M., \& Kushnir, I. I. (2020). Antagonistic activity of strains of lactic acid bacteria isolated \\ from Carpathian cheese. Regulatory Mechanisms in Biosystems, 11(4), 572-578. doi:10.15421/022089
}

Stepan Gzhytskyi

National University

of Veterinary Medicine

and Biotechnologies

(Lviv), Pekarska st., 50 ,

Lviv, 79010, Ukraine.

Tel.: +38-098-132-31-63.

E-mail:

musiyluba@ukr.net

A promising area for improving probiotics is the search for new sources of strains and the development of complex preparations which would include different types of bacterial cultures that complement each other. Sources of selection may be traditional dairy products, in particular, cheeses made from raw milk. Wild strains can be endowed with antibacterial properties. The antagonistic action of lactic acid bacteria $(\mathrm{LAB})$ has long attracted the attention of researchers and scientists. The aim of the study was to investigate the antagonistic activity against pathogenic and opportunistic microorganisms of LAB strains isolated from traditional Carpathian cheese. Three samples of cheese were selected for the research - one sample of brynza and budz (brynza before salting), made in the highlands of the Carpathians, and one sample of budz, made in the foothills. LAB were identified using classic microbiological and modern molecular genetic methods (RAPD-PCR, RFLP-PCR, 16S rRNA gene sequencing). The objects of our studies were five strains of LAB: Lactococcus lactis IMAU32258, L. garvieae JB2826472, Enterococcus durans FMA8, E. faecium L3-23, E. faecium IMAU9421. Technological parameters such as acid-forming activity of milk fermentation, resistance to high concentrations of $\mathrm{NaCl}$ and temperature optimums of cultivation were taken as the main criteria for assessing the suitability of LAB for inclusion in fermentation preparations. Antagonistic activity was determined by agar diffusion (agar well method) and optic density of test cultures using a Multiscan FC microplate reader (Thermo scientific, USA) at the wave of $620 \mathrm{~nm}$. There were four reference strains of pathogenic and opportunistic microorganisms were test cultures: Listeria monocytogenes PCM 2191, Staphylococcus aureus PCM 458, Escherichia coli PCM 2208, Salmonella typhimurium PCM 2182. Strains of the test cultures were received from the collection of microorganisms of the Institute of Biology and Biotechnology the (University of Rzeszów, Poland). According to the ability of LAB strains to form lactic acid, L. lactis IMAU32258 was the best acid-forming agent with an acid-forming energy of $94^{\circ} \mathrm{T}$. E. faecium was characterized by moderate levels of active and titratable acidity. Less pronounced acid-forming ability was determined for the species E. durans and L. garvieae. Cultures of the genus E. faecium, L. garvieae and E. durans were the most resistant to high concentrations of $\mathrm{NaCl}(6.5 \%)$. Regarding temperature optimums, we found that strains of $E$. faecium and $E$. durans species grew both at temperatures of 10,15 and $45^{\circ} \mathrm{C}$, whereas no growth of $L$. lactis IMAU32258 and $L$. garvieae JB282647 2 was observed at $45^{\circ} \mathrm{C}$. Among the studied bacteria, the strains of $E$. durans FMA8 and $E$. faecium L3-23 were characterized by the highest antagonistic activity in producing the largest zones of growth inhibition and optic density of pathogenic and opportunistic microorganisms. The strain L. garvieae JB282647 2 exhibited the lowest level of antagonistic activity against pathogenic and opportunistic microorganisms.

Keywords: brynza cheese; budz cheese, lactic acid bacteria; technological properties; antagonistic properties.

\section{Introduction}

Over the recent years, the scientists have been focussing more on antibacterial activity of lactic acid bacteria $(\mathrm{LAB})$ due to their important role in provision of microbiological quality of food products (Vasyliuk et al., 2014; Choi et al., 2018), prolongation of their storage period (Balciunas et al., 2013; Favaro et al., 2015), and also inhibition of pathogenic microflora and formation of microbiocenose of the gastrointestinal tracts of humans and animals (Chen et al., 2018). Antibacterial activity of LAB is determined by their adhesion to the mucous membrane of the intestine and correspondingly the decrease in the adhesion of pathogenic bacteria, aggregation and co-aggregation, and also production of antimicrobial substances such as organic acids, hydrogen peroxide and bacteriocins (Rahmeh et al., 2017).

Mechanisms of manifestation of antagonistic effect vary. In some cases antimicrobial effect of LAB occurs due to the influence of the main product of metabolism - lactic acid which reduces $\mathrm{pH}$ of environment and functions as a bactericidal factor (Castillo et al., 2015). In other cases antagonistic action is caused by neutral products, sometimes pigments produced by the cell into the environment. In oxygen, LAB can also produce hydrogen peroxide which inhibits a number of bacteria, for example
Staphylococcus aureus, Pseudomonas and others. Antimicrobial effect of hydrogen peroxide takes place as a result of denaturation of some enzymes, increase in penetrability of the membranes and decomposition of DNA under the impact of free radicals. Furthermore, hydrogen peroxide activates the lactoperoxidase system, and at the same time there forms hypothiocyanite - inhibitor of a broad range of Gram-positive and Gramnegative bacteria (Chornogor et al., 2006). Another known mechanism of antibacterial activity of LAB is the ability to produce lysozyme which destroys the wall of bacterial cells, creating a non-specific antibacterial barrier. Some LAB-producing substances are characterized by high antagonistic activity even at low concentrations in the environment. This category includes antibiotic substances (lactacyd, lactobrevin, nisin, lactobacillin, etc.) (Kamruzzaman et al., 2013; Deep \& Kundu, 2015). Among all LAB metabolites, bacteriocins deserve special attention due to their high potential for inhibiting activity towards pathogenic bacteria (Wang \& Liu, 2016; Ahn et al., 2017; Zhang et al., 2018). Bacteriocins are lowmolecular peptides or genetically-coded proteins which are synthesized on ribosomes and produced extracellularly (Cavicchioli et al., 2017; Yukalo \& Storozh, 2018). After binding with the surficial receptors or penetrating into target cells, bacteriocins can function in them through formation of pores, degradation of cellular DNA and inhibition of the system of pepti- 
doglycan synthesis. Bacteriocins may be used as biopreservatives added directly to the food product, or bacterio-cyanogenic strains of $\mathrm{LAB}$ which produce these peptides in situ may be added (Deegan et al., 2006).

Search for new LAB strains which can exert biological activity, particularly, antibacterial activity, is an important task of microbiology and biotechnology (Ajay et al., 2015). Valuable sources for isolating promising strains of lactic acid bacteria are natural econiches which have been formed over a long period of time, for example, traditional raw-milk dairy products from various geographical regions. Production of such products has an important place in the cultural heritage of each nation. A traditional Ukrainian food product is brined bryndza cheese (Slyvka et al., 2015b) which is made from sheep milk in non-industrial conditions. Over the process of preparation of bryndza out of raw milk, the bacterial cultures are not being added, thus over ripening the natural lactoacid microflora preserves. The current requirements to industrial LAB strains promising for inclusion in bacterial preparations include their safety, technological and probiotic properties (Zhang et al., 2016). Strains of bacterial preparations should be identified according to phenol- and geno-typical traits, have genetic ID, be stable, correspond to the technological requirements and have a broad spectrum of antagonistic properties against pathogenic and conditionally pathogenic microflora (Cavicchioli et al., 2015).

Today, since pathogenic microorganisms develop resistance to broadspectrum antibiotics, probiotic preparations are becoming more and more common. Because of the fact that probiotics based on lactic acid bacteria as the main inhabitants of the gastro-internal tract often have low antagonistic activity, scientists have focused their studies on seeking a culture with higher antagonistic activity (Moore et al., 2013). Antagonistic activity towards pathogenic and conditionally pathogenic strains can be different and vary for strains, underlying the main difference between the types of probiotics (Irkitova \& Grebenshchikova, 2018).

Lactic acid bacteria can be used instead of chemical preservatives for inhibition of growth of such pathogenic and conditionally pathogenic microorganisms as Listeria monocytogenes, Salmonella typhimurium, Staphylococcus aureus, Escherichia coli (Castillo et al., 2015; Langa et al., 2016). Currently there is a need for search of new probitics, which is explained by particularly selection of strains - disease pathogens unsusceptible to probiotic microorganisms (Abeer, 2018).

A promising orientation of improving probiotics is development of complex preparations which include different types of bacterial cultures which would complement each other's specificity of activity and effect on pathogenic and conditionally pathogenic microorganisms (Fijan, 2016). Therefore, study of antibacterial properties of strains of lactic acid bacteria isolated from natural econiches between which interrelations were determined is a relevant and timely task.

Thus, the objective of our study was antagonistic activity towards pathogenic and conditionally pathogenic microorganisms of LAB strains isolated from traditional Carpathian bryndza. As reference strains we used species of Gram-positive bacteria commonly present in milk and dairy products: S. aureus (Gazzola et al., 2020; Pacha et al., 2020), L. monocytogenes (Ricchi et al., 2019) and Gram-negative E. coli (Ribeiro et al., 2019), S. typhimurium (Amninder et al., 2020). Antibacterial activity of lactoacidic bacteria towards Gram-positive bacteria is studied more actively than Gram-negative bacteria (Heredia-Castro et al., 2015).

\section{Materials and methods}

Experimental studies of technological parameters and antagonistic activity of LAB strains were performed at the Institute of Biology and Biotechnology of the Rzeszów University (Republic of Poland). In the studies we used lactic acid bacteria isolated from bryndza made of raw sheep milk in non-industrial conditions of the Carpathian Region of Ukraine. The data on the origin of cheese are given in Table 1.

Cultures of LAB were identified using classic microbiological and modern molecular-genetic methods (RAPD-PCR, RFLP-PCR, 16S rRNA gene sequencing) (Slyvka et al., 2015a, 2015b). From three samples of cheese, made of milk of different breeds of sheep and selected from different regions with different climatic conditions, we identified the following LAB species: Lactococcus lactis, L. garvieae, Enterococcus faecium and E. durans (Slyvka et al., 2018). Therefore, we consider the species composition of such microflora to be typical for the traditional Carpathian bryndza. The objects of our studies were 5 species of LAB: $L$. lactis IMAU32258, L. garvieae JB2826472, E. durans FMA8, E. faecium L3-23 and E. faecium IMAU9421. Pure cultures of lactic acid bacteria were kept in $50 \%$ glycerol in the temperature of $80^{\circ} \mathrm{C}$. Before the experiment the cultures were activated by cultivation of MRS (de Man, Rogosa and Sharpe) broth in the temperature of $37^{\circ} \mathrm{C}$ over $24 \mathrm{~h}$.

\section{Table 1}

Origin of cheese samples

\begin{tabular}{cccc}
\hline $\begin{array}{c}\text { Kind of } \\
\text { cheese }\end{array}$ & $\begin{array}{c}\text { Designations of } \\
\text { samples hereinafter }\end{array}$ & $\begin{array}{c}\text { Location } \\
\text { of cheese selection }\end{array}$ & $\begin{array}{c}\text { Sheep } \\
\text { breed }\end{array}$ \\
\hline Bryndza & A & $\begin{array}{c}\text { Putyla, Chernivtsi Oblast } \\
\text { (highland) }\end{array}$ & $\begin{array}{c}\text { Ukrainian } \\
\text { Carpathian }\end{array}$ \\
\hline Budz* & B & $\begin{array}{c}\text { Putyla, Chernivtsi Oblast } \\
\text { (highland) }\end{array}$ & $\begin{array}{c}\text { Ukrainian } \\
\text { Carpathian }\end{array}$ \\
\hline Budz* & C & $\begin{array}{c}\text { Dana farm, Koteleve } \\
\text { Village, Chernivtsi Oblast } \\
\text { (pre-mountain area) }\end{array}$ & $\begin{array}{c}\text { Bucovina type } \\
\text { of Karakul } \\
\text { breed }\end{array}$ \\
\hline
\end{tabular}

Note: *-Budz sheep cheese according to the technology is Bryndza before salting.

Phylogenetical analysis was performed by determining forward nucleotide sequence of $16 \mathrm{~S}$ rRNA gene with following comparison of nucleotide identity with the sequences deposited in the International Gene Bank Data Base.

As the main criteria of evaluation of LAB cultures' suitability for inclusion in the fermentation starter preparation, we used the following technological parameters - acid-forming activity of milk fermentation, resistance to high concentrations of $\mathrm{NaCl}$ and temperature optimums for cultivation of lactic acid bacteria strains. Acid-forming activity was assessed according to the decrease in $\mathrm{pH}$ of defatted milk, fermented with corresponding bacterial strain. Lactic acid bacteria were incubated in sterile defatted milk without introduction of additional components, which was poured into $5 \mathrm{~mL}$ test tubes, and to which $1 \%$ inoculate was added, and incubated at the temperature of $30^{\circ} \mathrm{C}$ in a thermostat for 3 , $6,9,24 \mathrm{~h}$. Titratable acidity of milk was determined according to GOST 3624-92 "Milk and dairy products. Titrating methods of determining acidity". Active acidity was measured using Muttler Toledo MP220 electronic $\mathrm{pH}$-meter.

Salt resistance of the cultures of lactic acid bacteria was determined in 2.0, 4.0 and $6.5 \%$ concentrations of $\mathrm{NaCl}$. For this purpose, $0.5 \mathrm{~mL}$ of bacteria-inoculated MRS broth was added to the test tube with $5 \mathrm{~mL}$ of specially prepared broth for determining the ability of bacteria to grow in different concentrations of $\mathrm{NaCl}$. Test tubes were incubated in the temperature of $+30^{\circ} \mathrm{C}$ over 7 days. Change in the colour of broth in the test tube from violet to yellow indicated the ability of bacteria to develop in certain concentrations of $\mathrm{NaCl}$.

The ability of LAB strains to develop in different temperatures was determined at $+10,+15$ and $+45^{\circ} \mathrm{C}$. For this purpose, $0.5 \mathrm{~mL}$ of bacteriainoculated MRS broth was added to test tube with $5 \mathrm{~mL}$ of specially prepared broth. After the inoculation, test tubes were incubated for 7 days. Growth of cells in any of these temperatures was determined according to the change in the colour of the broth - violet to yellow.

Antagonistic activity of $\mathrm{LAB}$ was determined using the agar diffusion method (agar-well diffusion assay method) (Balouiri et al., 2016) and using Multiscan FC microplate reader manufactured by Thermo scientific (USA) at the wavelength of $620 \mathrm{~nm}$ (Jeong et al., 2018). Test-cultures were four reference strains of pathogenic and conditionally pathogenic microorganisms: Listeria monocytogenes PCM 2191, Staphylococcus aureus PCM 458, Escherichia coli PCM 2208, Salmonella typhimurium PCM 2182. Strains of test cultures were obtained from the collection of microorganisms at the Institute of Biology and Biotechnology of Rzeszów University (Republic of Poland). Strains of reference microorganisms were cultivated in nutrient broth (BTL sp. z.o.o., Poland) in the temperature of $37^{\circ} \mathrm{C}$ over $24 \mathrm{~h}$.

Daily cultures of lactic acid bacteria were grown in MRS broth at the temperature of $37^{\circ} \mathrm{C}$. During the study of antagonistic activity of LAB, we used culture broth and supernatant obtained by centrifuging the culture broth at $12,000 \mathrm{rpm}$ for $10 \mathrm{~min}$ at the temperature of $4{ }^{\circ} \mathrm{C}$ and subsequent filtration through filters of $0.22 \mu \mathrm{m}$ diameter (Minisart). Agar diffusion 
method was used in dense nutrient medium, comparing the sizes of growth inhibition zones of the test cultures. For this purpose, to Petri dishes with $25 \mathrm{~mL}$ of MRS agar (Himedia, India), we inoculated a lawn with corresponding cultures of conditionally pathogenic microorganisms in the amount of $100 \mu \mathrm{m}$ and concentration of $1 \times 10^{6} \mathrm{CFU} / \mathrm{cm}^{3}$. After keeping the Petri dishes for $1 \mathrm{~h}$ at the temperature of $37^{\circ} \mathrm{C}$, we made $6 \mathrm{~mm}$ wells in the agar medium using a special flambed dril bit and filled them with supernatant culture fluid in the amount of $100 \mu \mathrm{m}$. The Petri dishes were kept at the temperature of $5{ }^{\circ} \mathrm{C}$ for $2 \mathrm{~h}$ (for diffusion of culture broth and supernatant), and then subjected to incubation in aerobic conditions during $24 \mathrm{~h}$ in the temperature of $37^{\circ} \mathrm{C}$. Antagonistic activity of LAB strains was evaluated according to diameter of growth inhibition zones around the wells on the lawn of the test strains. Strains of LAB were considered inactive in case of producing growth inhibition zone of $0-5 \mathrm{~mm}(-), 5-10 \mathrm{~mm}$ $(+)$ - low active, 11-20 $\mathrm{mm}(++)$ - moderately active, over $20 \mathrm{~mm}(+++)$ highly active. Correspondigly the antagonistic activity of lactic acid bacteria were evaluated as "absent", "low", "moderate" and "high" (Vasyliuk et al., 2014).

Inhibition of growth of test cultures was also determined using microplate reader according to change in optical density of the mixture, measured at the wavelength of $620 \mathrm{~nm}$ in standard plates with 96 wells. Culture broth supernatants of the studied LAB strains were obtained from 24-h culture. Supernatants were mixed with pathogenic and conditionally pathogenic test cultures, adjusting to the optical density of 0.09-0.11, and then $200 \mu \mathrm{L}$ of the mixure was introduced to well of microplate. Microplate incubation was carried out at the temperature of $37{ }^{\circ} \mathrm{C}$ over $24 \mathrm{~h}$. Test cultures grown in the corresponding medium without supernatant were used as the control. Optical density of the mixture was determined at the beginning of incubation, after 2, 4, 6, 12, 20, 22 and $24 \mathrm{~h}$.

All the studies were performed in three replications. The data were statistically analyzed using Statistica 7.0 software (StatSoft Inc., USA). We calculated standard deviation (SD) and mean values (x). Differences between the values were considered reliable at $\mathrm{P}<0.05$ with taking into account Bonferroni correction.

\section{Results}

Determining nucleotide sequences of $16 \mathrm{~S}$ rRNA gene or complete nucleotide is currently the only accurate method of identification and differentiation of LAB. Phylogenetic analysis was conducted using the method of determining direct 16S rRNA gene nucleotide sequences. Sequence of 16S rRNA gene was compared with amplified fragments from the NCBI base (www.ncbi.nlm.nih.gov). Search for similarity of sequenced fragments was carried out using BLAST algorhythms available on the address (www.ncbi.nlm.nih.gov/blast). The results of the study are presented in Table 2. Determining nucleotide sequences allowed us to determine taxonomic position with homology of $99 \%$ for $4 \mathrm{LAB}$ isolates. Taxa were identified to 3 species: Lactococcus garvieae ssp., Enterococcus faecium ssp., Enterococcus durans ssp. We identified one strain of Lactococcus lactis ssp. lactis IMAU32258 with 90\% homology according to the forward primer, the data on nucleotide sequences according to the reverse primer is absent in the data base. The results we obtained using the comparative analysis of ribosomal gene sequences, together with phenotypical and biochemical characteristics, allowed us to accurately identify the studied LAB strains.

\section{Table 2}

Analysis of $16 \mathrm{~S}$ rDNA sequencing analysis (BLAST) of the LAB strains isolated from Carpathian cheese

\begin{tabular}{lccc}
\hline \multicolumn{1}{c}{ LAB strains } & $\begin{array}{c}\text { Strain } \\
\text { number }\end{array}$ & $\begin{array}{c}\text { Inventory number } \\
\text { in Gen Bank }\end{array}$ & $\begin{array}{c}\text { Percentage of } \\
\text { homology, \% }\end{array}$ \\
\hline Lactococcus lactis IMAU32258 & A5 & KF148942.1 & 90 \\
L. garvieae JB2826472 & B19 & KM409707.1 & 99 \\
Enterococcus faecium IMAU9421 & A8 & KF149589.1 & 99 \\
E. faecium L3-23 & C29 & KJ728981.1 & 99 \\
E. durans FMA8 & C31 & HQ721252.1 & 99 \\
\hline
\end{tabular}

Acid-producing activity of LAB strains over fermentation of defatted milk was measured quantitatively. The results of the dynamics of changes of titratable and active acidities of milk ( $\mathrm{pH}$ and ${ }^{\circ} \mathrm{T}$ ) in the conditions of cultivating LAB strains in it are presented in Table 3. According to the ability of lactic acid bacterial strains to produce lactic acid, the best acid producer was $L$. lactis with the energy of acid production over 24 hours accounting for $94.0 \pm 6.5^{\circ} \mathrm{T}$. Species $E$. faecium exhibited well acidproducing activity, the parameters of active and titratable acidities equaling $5.1 \pm 0.53 \mathrm{pH}$ and $83.0 \pm 4.9^{\circ} \mathrm{T}$ for IMAU9421 strain, and $4.93 \pm 0.44$ $\mathrm{pH}$ and $87.0 \pm 6.1^{\circ} \mathrm{T}$ for L3-23 respectively. Less expressed acidproducing ability was determined for E. durans $-5.18 \pm 0.68$ and $74.0 \pm$ 5.4 and L. garvieae $-5.33 \pm 0.24 \mathrm{pH}$ and $65.0 \pm 5.7^{\circ} \mathrm{T}$.

Table 3

Acid-forming activity of the LAB strains isolated from Carpathian cheese $(x \pm S D, n=3)$

\begin{tabular}{|c|c|c|c|c|c|c|c|c|}
\hline \multirow{2}{*}{ LAB strains } & \multicolumn{2}{|c|}{$3 \mathrm{~h}$} & \multicolumn{2}{|c|}{$6 \mathrm{~h}$} & \multicolumn{2}{|c|}{$9 \mathrm{~h}$} & \multicolumn{2}{|c|}{$24 \mathrm{~h}$} \\
\hline & active acidity, $\mathrm{pH}$ & titrated acidity, ${ }^{\circ} \mathrm{T}$ & active acidity, $\mathrm{pH}$ & titrated acidity, ${ }^{\circ} \mathrm{T}$ & active acidity, $\mathrm{pH}$ & titrated acidity, ${ }^{\circ} \mathrm{T}$ & active acidity, $\mathrm{pH}$ & titrated acidity, ${ }^{\circ} \mathrm{T}$ \\
\hline L. lactis IMAU32258 & $6.29 \pm 0.38^{*}$ & $39.0 \pm 3.8$ & $5.90 \pm 0.54$ & $45.0 \pm 4.5$ & $5.38 \pm 0.51$ & $65.0 \pm 5.9$ & $4.90 \pm 0.68$ & $94.0 \pm 6.5 *$ \\
\hline E. faecium IMAU9421 & $6.90 \pm 0.51$ & $34.0 \pm 3.2$ & $6.15 \pm 0.59$ & $41.0 \pm 5.3$ & $5.50 \pm 0.40$ & $56.0 \pm 4.1$ & $5.01 \pm 0.53$ & $83.0 \pm 4.9$ \\
\hline L. garvieae JB282647 2 & $6.65 \pm 0.42$ & $33.0 \pm 4.1$ & $6.30 \pm 0.52$ & $42.0 \pm 4.6$ & $5.86 \pm 0.67$ & $49.0 \pm 5.0$ & $5.33 \pm 0.24$ & $65.0 \pm 5.7$ \\
\hline E. faecium $\mathrm{L} 3-23$ & $6.61 \pm 0.35$ & $34.0 \pm 4.3$ & $6.17 \pm 0.46$ & $42.0 \pm 4.9$ & $5.67 \pm 0.48$ & $54.0 \pm 5.7$ & $4.93 \pm 0.44$ & $87.0 \pm 6.1$ \\
\hline E. durans FMA8 & $6.58 \pm 0.36$ & $34.0 \pm 3.3$ & $6.15 \pm 1.04$ & $42.0 \pm 4.7$ & $5.87 \pm 0.82$ & $50.0 \pm 4.2$ & $5.18 \pm 0.68$ & $74.0 \pm 5.4$ \\
\hline
\end{tabular}

Note: * - values significantly different one from another within a column on the results of comparison $(\mathrm{P}<0.05)$ with Bonferroni correction.

Resistance of lactic acid bacteria to high concentrations of $\mathrm{NaCl}$ measured 5\% (for production of bryndza from pasteurized sheep milk) and $7 \%$ (for production of bryndza from raw sheep milk) is one of important aspects for selecting cultures for production of bryndza. The results of growth activity of bacterial cultures in various concentrations of $\mathrm{NaCl}$ and different temperatures are given in Table 4. Highest resistances to high concentration of $\mathrm{NaCl}(6.5 \%)$ were demonstrated by the cultures of E. faecium, L. garvieae and E. durans. The strain of L. lactis IMAU32258 was characterized by higher sensitivity to heightened concentration of salt, and manifested no growth in the concentration of $6.5 \%$.

As for temperature optima, we determined that strains of $E$. faecium and $E$. durans grew at the temperatures of $10,15^{\circ} \mathrm{C}$, as well as at $45^{\circ} \mathrm{C}$, whereas $L$. lactis and $L$. garvieae did not grow at the temperature of $45^{\circ} \mathrm{C}$.

During the study of antagonistic activity of LAB strains isolated from the Carpathian bryndza, we determined that they have different extent of inhibiting effect on the test cultures (Table 5). During the use of the culture broth, the highest antagonistic activity was determined for strain of E. durans, with growth inhibition zone measuring $20 \mathrm{~mm}$ and more for all test cultures used in the study. The strain of $L$. garvieae exerted low-active antagonistic activity towards pathogenic microorganisms, producing growth inhibition zones of 8.4-10.2 mm. Among strains of E. faecium, the highest antagonistic activity was displayed by L3-23 strain. Highly active antagonistic activity was also exhibited by $L$. lactis. Except $L$. garvieae, high succeptiblity to all the strains of lactic acid bacteria was seen in test culture of S. typhimurium PCM 2182, growth inhibition zone measuring $20.3 \pm 1.7 \mathrm{~mm}$ to $24.1 \pm 1.2 \mathrm{~mm}$.

\section{Table 4}

Growth characteristics of the strains at different $\mathrm{NaCl}$ concentration and temperature

\begin{tabular}{lccccccc}
\hline \multirow{2}{*}{ LAB strains } & \multicolumn{3}{c}{$\mathrm{NaCl} \%$} & \multicolumn{4}{c}{ Temperature, ${ }^{\circ} \mathrm{C}$} \\
\cline { 2 - 7 } & 2.0 & 4.0 & 6.5 & 10 & 15 & 45 \\
\hline L. lactis IMAU32258 & + & + & - & + & + & - \\
E. faecium IMAU9421 & + & + & + & + & + & + \\
L. garvieae JB2826472 & + & + & + & + & + & - \\
E. faecium L3-23 & + & + & + & + & + & ++ \\
E. durans FMA8 & + & + & + & + & + & + \\
\hline
\end{tabular}

Note: + good growth; + growth; - no growth. 
Lactic acid bacteria are given attention as potential probiotics due to their properties to produce antibiotic substances of various nature, including bacteriocins, mostly, of peptide or protein nature. Therefore, the next stage was the study of antagonistic activity of culture broth supernatant of the studied strains of lactic acid bacteria against conditionally pathogenic microorganisms (Table 6). We determined that growth-inhibiting effect of supernatants of the studied strains of lactic acid bacteria on the test cultures varied. Supernatants of the strains of lactic acid bacteria poorly inhibited growth of $S$. aureus, contrast to the results obtained using culture broth. The difference between the growth inhibition zones produced by culture broth and supernatant equaled 8-12 mm. Obviously the inhibition of growth of $S$. aureus is participated by cells or their components.

Table 5

Antagonistic effect of the LAB strains (culture fluid) isolated from Carpathian cheese against pathogenic bacteria $(\mathrm{mm}, \mathrm{x} \pm \mathrm{SD}, \mathrm{n}=3)$

\begin{tabular}{lcccc}
\hline \multicolumn{1}{c}{ LAB strains } & $\begin{array}{c}\text { S. aureus } \\
\text { PCM458 }\end{array}$ & $\begin{array}{c}\text { L. mono- } \\
\text { cytogenes } \\
\text { PCM2191 }\end{array}$ & $\begin{array}{c}\text { S.typhi- } \\
\text { murium } \\
\text { PCM2182 }\end{array}$ & $\begin{array}{c}\text { E. coli } \\
\text { PCM 2208 }\end{array}$ \\
\hline L. lactis IMAU32258 & $20.2 \pm 2.8$ & $18.5 \pm 1.6$ & $24.1 \pm 1.9$ & $18.7 \pm 1.6$ \\
E. faecium IMAU9421 & $18.1 \pm 1.4$ & $14.4 \pm 1.3$ & $20.3 \pm 1.7$ & $23.6 \pm 2.4$ \\
L. garvieae JB2826472 & $8.4 \pm 1.1^{*}$ & $10.2 \pm 0.9^{*}$ & $9.5 \pm 1.4^{*}$ & $8.4 \pm 0.7^{*}$ \\
E. faecium L3-23 & $19.5 \pm 1.6$ & $21.4 \pm 0.8$ & $25.2 \pm 1.2$ & $20.1 \pm 1.2$ \\
E. durans FMA8 & $20.6 \pm 2.1$ & $23.6 \pm 1.3$ & $24.0 \pm 0.9$ & $20.3 \pm 1.9$ \\
\hline
\end{tabular}

Note: * - values significantly different one from another within a column on the results of comparison $(\mathrm{P}<0.05)$ with Bonferroni correction.

Strain L. garvieae JB2826472 displayed the highest degree of antagonistic activity towards pathogenic and conditionally pathogenic microorganisms $(6.2-7.4, \mathrm{P}<0.05)$. At the same time, E. faecium IMAU9421 exerted moderate antagonistic impact on all the test cultures, whereas activity of E. faecium L3-23 was higher. In all the variants of the experi- ment, a high level of antagonistic activity was exerted by $E$. durans, particularly towards L. monocytogenes PCM 2191 (growth inhibition zone of $22.6 \pm 1.8 \mathrm{~mm}$ ) and S. typhimurium PCM 2182 (growth inhibition zone measuring $23.8 \pm 1.2 \mathrm{~mm}$ ), which may suggest using this strain for developing a probiotic of metabolite type as a constituent in bacterial preparations.

\section{Table 6}

Antagonistic effect of the LAB strains (supernatant) isolated from Carpathian cheese against pathogenic bacteria $(\mathrm{mm}, \mathrm{x} \pm \mathrm{SD}, \mathrm{n}=3)$

\begin{tabular}{lcccc}
\hline \multicolumn{1}{c}{ LAB strains } & $\begin{array}{c}\text { S. aureus } \\
\text { PCM 458 }\end{array}$ & $\begin{array}{c}\text { L. mono- } \\
\text { cytogenes } \\
\text { PCM 2191 }\end{array}$ & $\begin{array}{c}\text { S.typhi- } \\
\text { murium } \\
\text { PCM2182 }\end{array}$ & $\begin{array}{c}\text { E. coli } \\
\text { PCM2208 }\end{array}$ \\
\hline L. lactis IMAU32258 & $8.4 \pm 1.3$ & $17.1 \pm 1.2$ & $18.9 \pm 0.6$ & $17.3 \pm 2.1$ \\
L. garvieae JB2826472 & $6.3 \pm 0.9$ & $6.2 \pm 0.4^{*}$ & $7.4 \pm 1.3^{*}$ & $7.1 \pm 1.3^{*}$ \\
E. faecium IMAU9421 & $6.1 \pm 0.6$ & $14.3 \pm 2.1$ & $15.7 \pm 1.7$ & $16.5 \pm 1.5$ \\
E. faecium L3-23 & $10.2 \pm 1.7$ & $18.5 \pm 1.7$ & $20.1 \pm 2.5$ & $18.4 \pm 2.7$ \\
E. durans FMA8 & $12.5 \pm 2.9$ & $22.6 \pm 1.8$ & $23.8 \pm 1.2$ & $20.4 \pm 1.4$ \\
\hline
\end{tabular}

Note: see Table 5 .

The extent of inhibition of growth of test-cultures in the dynamics is determined according to the change in optical density of their culture broth after addition to supernatant of lactic acid bacteria and incubation for $24 \mathrm{~h}$ in the temperature of $37^{\circ} \mathrm{C}$ (Fig. 1).

The survey results presented in the figures indicate that each of bacteria of the test-cultures had a specific curve of increase. Over $24 \mathrm{~h}$ of incubation of test cultures, the optical density of $S$. aureus increased to 0.512 ; for $L$. monocytogenes increased to 0.934 , for $S$. typhimurium - to 0.65 , and for $E$. coli - to 0.89 . Active increase in optical density for all the test cultures occurred over the first two hours of cultivation. The lowest level of antagonistic activity of LAB was determined towards $S$. aureus, as indicated in the greatest value of optical density of its culture broth.
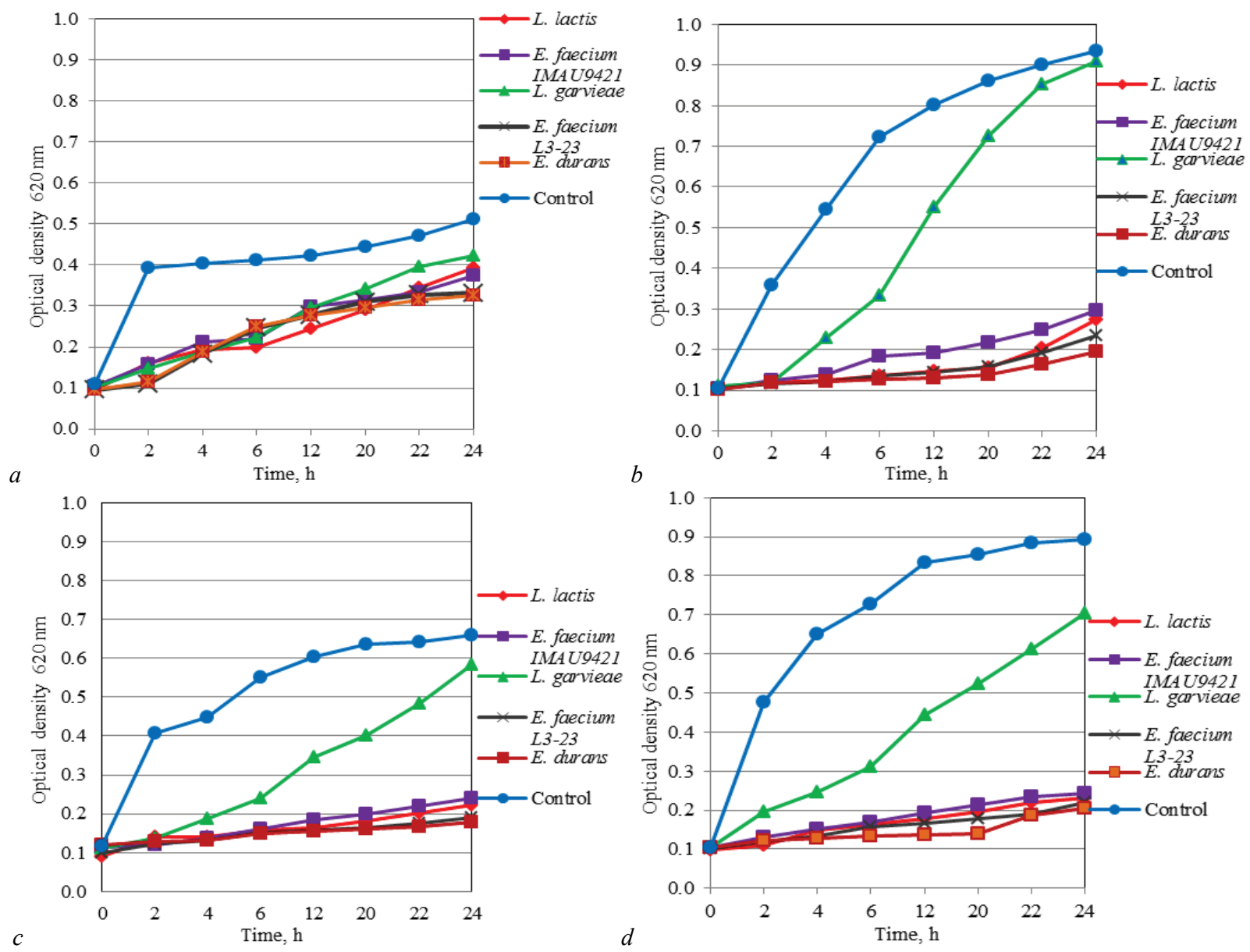

Fig. 1. Antagonistic activities of the supernatant $L A B$ at $37^{\circ} \mathrm{C}$ for $24 \mathrm{~h}$ : a-Staphylococcus aureus PCM 458, b - Listeria monocytogenes PCM 2191, c-Salmonella typhimurium PCM 2182, $d$-Escherichia coli $\mathrm{PCM} 2208$; control - growth of pathogenic bacteria without the supernatant from $\mathrm{LAB} ; \mathrm{x} \pm \mathrm{SD}, \mathrm{n}=3$ 

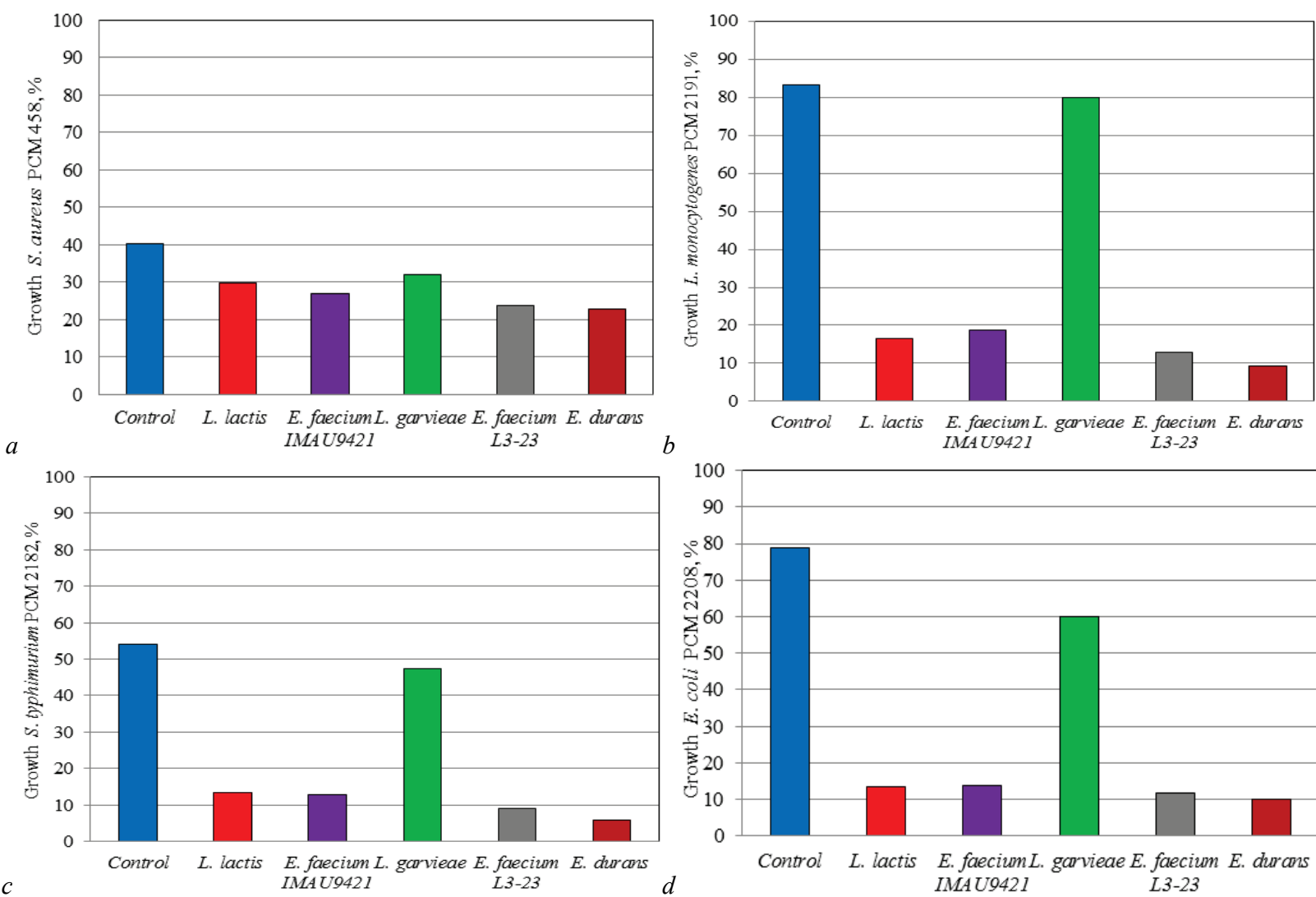

Fig. 2. Inhibition of pathogenic bacterial growth in the presence of the supernatant from LAB:

a-Staphylococcus aureus PCM 458, b-Listeria monocytogenes PCM 2191, c-Salmonella typhimurium PCM 2182, $d$-Escherichia coli PCM 2208 ;

control - growth of pathogenic bacteria without the supernatant from LAB; the bacterial growth was determined at OD $620 \mathrm{~nm} ; \mathrm{x} \pm \mathrm{SD}, \mathrm{n}=3$

We performed cultivation in aerobic conditions, therefore we cannot differentiate the factors due to which the antagonistic activity was displayed - i.e. bacteriocins, hydrogen peroxide, organic acids or enzymes.

We determined that $E$. durans FMA8 strain was characterized by high antagonistic activity towards L. monocytogenes and S. typhimurium, optical densities of which after $24 \mathrm{~h}$ of cultivation accounted for 0.195 and 0.178 respectively (Fig. 1b, c), i.e. practically at the initial level. High extent of antagonism was exerted by $E$. durans FMA8 strain against $E$. coli (Fig. 1d). Strain L. garvieae JB2826472 took lowest-degree antagonistic impact on pathogenic and conditionally pathogenic microorganisms in the conditions of using agar diffusion technique and change in optical density. Other surveyed strains also demonstrated higher antagonistic activity.

In the analysis of the graphs which reflect the antibacterial activities of LAB strains (Fig. 2), we should note that the most active strain was $E$. durans FMA8 - growth of L. monocytogenes equaled only 9.3\% compared with $83.1 \%$ in the control (without addition of supernatant of LAB), S. typhimurium $-5.8 \%$ compared with $54.0 \%$ in the control, and E. coli$10.0 \%$ compared with $78.0 \%$ in the control. Supernatants of strains $L$. lactis IMAU32258, E. faecium IMAU9421 and E. faecium L3-23 were also quite active in inhibiting growth of all the test cultures, except $S$. aureus, though strains $E$. faecium $\mathrm{L} 3-23$ and $E$. durans FMA8 decreased the intensity of its growth by over $30 \%$.

\section{Discussion}

While selecting LAB strains in accordance with their properties, it is important to take into consideration the extent and velocity of acid production of bacterial microorganisms, temperature optima and resistance to high concentrations of salt, because this directly influences the speed of obtaining end product and interaction with other constituents of bacterial preparation, taste of the product, its physical qualities and maintenance (Thierry et al., 2015). Species E. faecium exerted high acid producing ability, which is consistent with the results (Amaral et al., 2016). Less expressed acid-producing ability was determined for E. durans and
L. garvieae. Low acid-producing ability of $L$. garvieae of dairy origin was reported in the study (Fortina et al., 2007). Several surveys confirm high technological practicability of $E$. faecium and $E$. durans (McAuley et al., 2015) and good combination with both mesophious and thermophilous cultures (Sarantinopoulos et al., 2002). Regarding salt-tolerance, according to the results of the study (Amaral et al., 2017), the salt concentrations of $5 \%$ and $7 \%$ were limiting factors for $E$. durans SJRP29, which does not correlate with our results and indicates strain differences, at the same time our results confirm broad temperature range for growth of enterococci.

High antibacterial activity is one of the main requirements to probiotic strains (Yerlikaya \& Akbulut, 2019). Among the surveyed lactic acid bacteria, the lowest antagonistic activities towards both Gram-positive and Gram-negative test-cultures were exerted by strain L. garvieae JB2826472. These data are completely consistent with the data obtained using the agar diffusion method, though they do not coincide with reports about high antagonistic activity of this species against $S$. aureus (Abdelfatah \& Mahboub, 2018). At the same time, the authors emphasize that this high antibacterial activity manifested according to the results of their studies is due to synthesis of bacteriocins, because the cultivation was performed in anaerobic conditions, having supernatant neutralized before the introduction. Several hypotheses are proposed to explain the differences between the expressions of antibacterial activity of culture broth and supernatant towards $S$. aureus, one of which is adsorption of bacteriocin-like compounds by the filter. Our data about low antibacterial activity of supernatant of LAB against $S$. aureus correlate with other reports (Ammor et al., 2006; Rasovic et al., 2017). It should be noted that the differences between antibacterial activities of culture broth and supernatant of the other testcultures were much less manifested. Notable antibacterial impact was taken by E. durans FMA8 on L. monocytogenes - one of the most dangerous pathogens in food products, which causes high mortality rates (Swaminathan \& Gerner-Smidt, 2007). Presence of L. monocytogenes in cheeses is disturbing, contamination by $L$. monocytogenes was reported for example in cheese-making factories in Brazil (Barancelli et al., 2014), and cheeses are consumed without undergoing processing. Therefore, supernatants of strains E. faecium L3-23 and E. durans FMA8 exerted 
well expressed antagonistic activity towards strains of S. typhimurium PCM 2182 and E. coli PCM 2208 and L. monocytogenes PCM 2191 and low activity against $S$. aureus, entirely correlating with the results obtained using method of diffusion of supernatant in agar. The ability of enterococci to exert antibacterial impact due to synthesis of bacteriocins is reported in a number of studies (Altuntaş et al., 2014; Cavicchioli et al., 2015). Strain L. garvieae JB2826472 had the lowest antagonistic impact on pathogenic and conditionally pathogenic microorganisms. Unlike $L$. garvieae JB2826472, strains $L$. lactis IMAU32258 and E. faecium IMAU9421 exhibited moderate antagonistic activity.

We determined no significant differences between antagonistic activities of the studied strains against conditionally and conditionally pathogennic bacteria, which is consistent with a number of studies (de Almeida et al., 2015; Reuben et al., 2019). However, Anas et al. (2008) reported that LAB exert a higher level of antagonistic activity towards Grampositive than Gram-negative bacteria. Lactic acid bacteria can produce bacteriocins which have an antibacterial impact on such Gram-negative bacteria as E. coli, S. typhimurium, Helicobacter pylori NCIPD 230, and also Campylobacter jejuni (Todorov et al., 2010; Reis et al., 2012).

According to the results of the study on the representatives of Enterococcus genus, E. faecium and $E$. durans may have other probiotic properties (Amaral et al., 2016). Combination use of E. faecium and E. durans would allow creation of a bacterial composition for production of dairy products with probiotic properties. Enterococci are part of the normal microflora of the human intestine, and are currently being considered as probiotics (Goh \& Philip, 2015), and also cultures for enrichment of taste and aroma properties of dairy products, first of all cheeses (Yerlikaya \& Akbulut, 2019). Species L. garvieae is identified to potentially pathogenic species which causes diseases in fishes (Vendrell et al., 2006), though it was isolated from raw milk and cheeses as well (Fernández et al., 2010), the genetic similarity between the specimens from different sources (fishes and dairy products) being insignificant (Foschino et al., 2008). It is worth noting that no relationship was determined between consumption of products from raw milk and $L$. garvieae-caused infections (Fernández et al., 2010). We isolated $L$. garvieae from all the samples of Carpathian brynd$\mathrm{za}$, though there is little literature data on its presence in dairy products. Species $L$. garvieae is known for producing a number of bacteriocins (Tosukhowong et al., 2012; Maldonado et al., 2013; Ovchinnikov et al., 2016) and is currently considered from the perspective of possible control of pathogenic microflora (Abdelfatah \& Mahboub, 2018).

\section{Conclusions}

We identified strains of lactic acid bacteria isolated from Carpathian bryndza. According to nucleotide sequences, we determined taxonomic position with homology of $99 \%$ for 4 isolates of LAB. Taxa belonged to three species: Lactococcus garvieae ssp., Enterococcus faecium ssp., Enterococcus durans ssp. We identified one strain Lactococcus lactis ssp. lactis IMAU32258 with homology of $90 \%$ according to forward primer.

We analyzed technological properties of the isolated strains. According to the property of LAB strains to produce lactic acid, the best acid producer was L. lactis IMAU32258 with the energy of acid-production equaling $94^{\circ}$ T. Species E. faecium was observed to have moderate parameters of active and titratable acidity. Less expressed acid-producing ability was determined for $E$. durans and $L$. garvieae. Greatest resistance to high concentrations of $\mathrm{NaCl}(6.5 \%)$ was exerted by cultures of $E$. faecium, L. garvieae and E. durans. As for the temperature optima, we determined that strains of $E$. faecium and $E$. durans grew at the temperatures of $10,15{ }^{\circ} \mathrm{C}$, as well as $45^{\circ} \mathrm{C}$, whereas no growth of $L$. lactis IMAU32258 and $L$. garvieae JB282647 2 was observed at the temperature of $45^{\circ} \mathrm{C}$.

As a result of the performed studies, we determined antagonistic activity of 5 strains of lactic acid bacteria. Among the surveyed bacteria, the most active were strains $E$. durans FMA8 and $E$. faecium L3-23, producing the greatest growth inhibition zones of pathogenic and conditionally pathogenic microorganisms while using the agar diffusion technique, and also according to the change in optical density when using a microplate reader. Strain L. garvieae JB2826472 exerted the highest level of antago- nistic activity against pathogenic and conditionally pathogenic microorganisms.

\section{References}

Abdelfatah, E. N., \& Mahboub, H. H. H. (2018). Studies on the effect of Lactococcus garvieae of dairy origin on both cheese and Nile tilapia $(O$. niloticus). International Joumal of Veterinary Science and Medicine, 6(2), 201-207.

Abeer, A. Z. (2018). Study the effect of probiotic bacteria isolated from foods on pathogens. Biomedical Research, 29(12), 2509-2515.

Ahn, H., Kim, J., \& Kim, W. J. (2017). Isolation and characterization of bacteriocinproducing Pediococcus acidilactici HW01 from malt and its potential to control beer spoilage lactic acid bacteria. Food Control, 80, 59-66.

Ajay, G. C., Gunaseelan, D., Sushma, N., Ramkrishna, S., \& Utpal, R. (2015). An antimicrobial metabolite from Bacillus sp.: Significant activity against pathogenic bacteria including multidrug-resistant clinical strains. Frontiers in Microbiology, 6, 1335.

Altuntaş, E. G., Ayhan, K., Peker, S., Ayhan, B., \& Demiralp, D. O. (2014). Purification and mass spectrometry based characterization of a pediocin produced by Pediococcus acidilactici 13. Molecular Biology Reports, 41, 6879-6885.

Amaral, D. M. F., Silva, L. F., Casarotti, S. N., Nascimento, L. C., \& An, L. B. (2016). Penna Enterococcus faecium and Enterococcus durans isolated from cheese: Survival in the presence of medications under simulated gastrointestinal conditions and adhesion properties. Journal of Dairy Science, 100, 933-949.

Amninder, S. S., Arshdeep, S., \& Minto, M. (2020). Decimal log reductions of Salmonella Senftenberg $775 \mathrm{~W}$ and other Salmonella serovars in nonfat milk and powder. Journal of Dairy Science, 103, 6894-6899.

Anas, M., Eddine, H. J., \& Mebrouk, K. (2008). Antimicrobial activity of Lactobacillus species isolated from Algerian raw goat's milk against Staphylococcus aureus. World Journal of Dairy and Food Sciences, 3, 39-49.

Balouiri, M., Sadiki, M., \& Koraichilbnsouda, S. (2016). Methods for in vitro evaluating antimicrobial activity: A review. Journal of Pharmaceutical Analysis, 6(2), 71-79.

Barancelli, G. V., Camargo, T. M., Gagliardi, N. G., Porto, E., Souza, R. A., Campioni, F., Falcao, J. P., Hofer, E., Cruz, A. G., \& Oliveira, C. A. F. (2014). Pulsedfield gel electrophoresis characterization of Listeria monocytogenes isolates from cheese manufacturing plants in Sao Paulo, Brazil. International Journal of Food Microbiology, 173, 21-29.

Castillo, P. M., Díaz, A., \& Durán, M. (2015). Antagonistic action of Lactobacillus spp. against Staphylococcus aureus in cheese from Mompox - Colombia. Revista Facultad Nacional de Agronomía Medellín, 68(2), 7721-7727.

Cavicchioli, V. Q., Camargo, A. C., Todorov, S. D., \& Nero, L. A. (2017). Novel bacteriocinogenic Enterococcus hirae and Pediococcus pentosaceus strains with antilisterial activity isolated from Brazilian artisanal cheese. Journal of Dairy Science, 100, 2526-2535.

Cavicchioli, V. Q., Dornellas, W. S., Perin, L. M., Pieri, F. A., Franco, B. D. G. M., Todorov, S. D., \& Nero, L. A. (2015). Genetic diversity and some aspects of antimicrobial activity of lactic acid bacteria isolated from goat milk. Applied Biochemistry and Biotechnology, 175, 2806-2822.

Chen, X., Zhang, J., Yi, R., Mu, J., Zhao, X., \& Yang, Z. (2018). Hepatoprotective effects of Lactobacillus on carbon tetrachlorideinduced acute liver injury in mice. International Journal of Molecular Sciences, 19, 2212.

Choi, A. R., Patra, J. K., Kim, W. J., \& Kang, S. S. (2018). Antagonistic activities and probiotic potential of lactic acid bacteria derived from a plant-based fermented food. Frontiers in Microbiology, 9, 1-12.

Chornogor, N. P., Bolshakova, V. L., \& Vinnikov, A. I. (2006). Antagonistychna aktyvnist molochnokyslyh bakterij [Antagonistic activity of lactic acid bacteria]. Biosystems Diversity, 14(2), 187-191 (in Ukrainian).

de Almeida, J. W. L. G., Ferrari, Í. S., de Souza, J. V., da Silva, C. D. A., da Costa, M. M., \& Dias, F. S. (2015). Characterization and evaluation of lactic acid bacteria isolated from goat milk. Food Control, 53, 96-103.

Deegan, L. H., Cotter, P. D., Hill, C., \& Ross, P. (2006). Bacteriocins: Biological tools for bio-preservation and shelf-life extension. International Dairy Journal, $16,1058-1071$.

Deep, S., \& Kundu, S. (2015). Assessment of preliminary in vitro probiotic characterstics of the folate producing yogurt starter culture Streptococcus and Lactobacillus species. Journal of Pharmacy and Biological Sciences, 10(3), 26-31.

Favaro, L., Penna, A. L. B., \& Todorov, S. D. (2015). Bacteriocinogenic LAB from cheeses - application in biopreservation? Trends in Food Science and Technology, 41, 37-48.

Fernández, E., Alegría, A., Delgado, S., \& Mayo, B. (2010). Phenotypic, genetic and technological characterization of Lactococcus garvieae strains isolated from a raw milk cheese. International Dairy Journal, 20, 142-148.

Fijan, S. (2016). Antimicrobial effect of probiotics against common pathogens. Probiotics and Prebiotics in Human Nutrition and Health, 2016, 191-221.

Fortina, M. G., Ricci, G., Foschino, R., Picozzi, C., Dolci, P., \& Zeppa, G. (2007). Phenotypic typing, technological properties and safety aspects of Lactocoç45 
garvieae strains from dairy environments. Journal of Applied Microbiology, $103,445-453$.

Foschino, R., Nucera, D., Volponi, G., Picozzi, C., Ortoffi, M., \& Bottero, M. T. (2008). Comparison of Lactococcus garvieae strains isolated in northern Italy from dairy products and fishes through molecular typing. Journal of Applied Microbiology, 105, 652-662.

Gazzola, A., Maisano, A. M., Bianchini, V., Vezzoli, F., Romanò, A., Graber, H. U., Cremonesi, P., Zanardi, G., Cappa, V., \& Luini, M. (2020). Characterization of Staphylococcus aureus from bulk tank milk of dairy cattle in Lombardy (Northem Italy). Journal of Dairy Science, 103, 2685-2692.

Goh, H. F., \& Philip, K. (2015). Isolation and mode of action of bacteriocin BacCl producedby nonpathogenic Enterococcus faecium C1. Journal of Dairy Science, 98(8), 5080-5090.

Heredia-Castro, P. Y., Méndez-Romero, J. I., Hernández-Mendoza, A., Acedo-Félix, E., González-Córdova, A. F., \& Vallejo-Cordoba, B. (2015). Antimicrobial activity and partial characterization of bacteriocinlike inhibitory substances produced by Lactobacillus spp. isolated from artisanal Mexican cheese. Journal of Dairy Science, 98, 8285-8293.

Irkitova, A. N., \& Grebenshchikova, A. V. (2018). Antimicrobial action of a bacterial consortium containing strains of the genus Bacillus. Ukrainian Journal of Ecology, 8(4), $444-449$ (in Ukrainian).

Jeong, D., Kim, D. H., Song, K. Y., \& Seo, K. H. (2018). Antimicrobial and antibiofilm activities of Lactobacillus kefiranofaciens DD2 against oral pathogens. Journal of Oral Microbiology, 10(1), 1472985.

Kamruzzaman, M., Jahan, S., Fuadh-Al-Kabir, M., Sarowar, J. M., Rahman, M., Ahsanul, K. K., Chowdhury, R., \& Hossain, S. (2013). The investigation of probiotic potential of lactic acid bacteria isolated from cow milk. International Journal of Biosciences, 3(4), 161-167.

Langa, S., Martín-Cabrejas, I., Montiel, R., Peirotén, Á., Arqués, J. L., \& Medina, M. (2016). Protective effect of reuterin-producing Lactobacillus reuteri against Listeria monocytogenes and Escherichia coli O157:H7 in semi-hard cheese. Food Control, 84, 284-289.

Maldonado, B. A., Cárdenas, N., Martínez, B., Ruiz-Barba, J. L., Fernández-Garayzábal, J. F., \& Rodríguez, J. M. (2013). Novel class IId bacteriocin from Lactococcus garvieae that inhibits septum formation in L. garvieae strains. Applied and Environmental Microbiology, 79, 4336-4346.

McAuley, C. M., Britz, M. L., Gobius, K. S., \& Heather, C. M. (2015). Prevalence, seasonality, and growth of enterococci in raw and pasteurized milk in Victoria, Australia. Journal of Dairy Science, 98, 8348-8358.

Moore, T., Globa, L., Barbaree, J., Vodyanoy, V., \& Sorokulova, I. (2013). Antagonistic activity of Bacillus bacteria against food-borne pathogens. Journal of Probiotics and Health, 1(3), 110.

Ovchinnikov, K. V., Chi, H., Mehmeti, I., Holo, H., Nes, I., \& Diep, D. B. (2016). Novel group of leaderless multipeptide bacteriocins from gram-positive bacteria. Applied and Environmental Microbiology, 82, 5216-5224.

Pacha, P. A., Munoz, M. A., Paredes-Osses, E., \& Latorre, A. A. (2020). Virulence profiles of Staphylococcus aureus isolated from bulk tank milk and adherences on milking equipment on Chilean dairy farms. Journal of Dairy Science, 103(5), 4732-4737.

Rahmeh, R., Akbar, A., Kishk, M., Al Onaizi, T., Al-Shatti, A., Shajan, A., Batool, A., Al-Mutairi, S., \& Awatef, Y. (2018). Characterization of semipurified enterocins produced by Enterococcus faecium strains isolated from raw camel milk. Journal of Dairy Science, 101, $4944-4952$.

Rasovic, M. B., Mayrhofer, S., Martinovic, A., Durr, K., \& Domog, K. J. (2017). Lactococci of local origin as potential starter cultures for traditional Montenegrian production. Food Technology and Biotechnology, 55(1), 55-66.

Reis, J. A., Paula, A. T., Casarotti, S. N., \& Penna, A. L. B. (2012). Lactic acid bacteria antimicrobial compounds: Characteristics and applications. Food Engineering Review, 4, 124-140.

Reuben, R. C., Roy, P. C., Sarkar, S. L., Rubayet, A. S. M., Alam, U., \& Jahid, I. K. (2019). Characterization and evaluation of lactic acid bacteria from indigenous raw milk for potential probiotic properties. Journal of Dairy Science, 103, 1223-1237.
Ribeiro Júnior, J. C., Silva, F. F., Lima, J. B. A., Ossugui, E. H., Teider Junior, P. I., Campos, A. C. L. P., Navarro, A., \& Tamanini, R. (2019). Molecular characterization and antimicrobial resistance of pathogenic Escherichia coli isolated from raw milk and Minas Frescal cheeses in Brazil. Journal of Dairy Science, 102(12), 10850-10854.

Ricchi, M., Scaltriti, E., Cammi, G., Garbarino, C., Arrigoni, N., Morganti, M., \& Pongolini, S. (2019). Persistent contamination by Listeria monocytogenes of bovine raw milk investigated by whole-genome sequencing. Journal of Dairy Science, 102, 6032-6036.

Sarantinopoulos, P., Kalantzopoulos, G., \& Tsakalidou, E. (2002). Effect of Enterococcus faecium on microbiological, physicochemical and sensory characteristics of Greek Feta cheese. International Journal of Food Microbiology, 76, 93-105.

Slyvka, I. M., Tsisaryk, O. Y., \& Botser, T. (2015a). Vydilennja ta identyfikacija molochnokyslyzh bakterij za dopomogoju metodu RFLP-PCR genu 16s rRNK [Isolation and identification of lactic acid bacteria using the method RFLP-PCR gene 16s rRNK]. Biologija Tvaryn, 17(1), 109-117 (in Ukrainian).

Slyvka, I. M., Tsisaryk, O. Y., \& Botser, T. (2015b). Identyfikacija molochnokyslyh bakterij iz zastosuvannjam kompleksu molekuljarno-genetychnyh metodiv [Identification of lactic acid bacteria using a set of molecular genetic methods]. Naukovyj Visnyk Lvivskogo Nacionalnogo Universytetu Veterynarnoji Medycyny ta Biotehnologij imeni Gzhyckogo, 17(1), 201-210 (in Ukrainian).

Swaminathan, B., \& Gerner-Smidt, P. (2007). The epidemiology of human listeriosis. Microbes and Infection, 9, 1236-1243.

Thierry, A., Valence, F., Deutsch S.-M., Even, S., Falentin, H., Le Loir, Y., Jan, G., \& Gagnaire, V. (2015). Strain-to-strain differences within lactic and propionic acid bacteria species strongly impact the properties of cheese - A review. Dairy Science and Technology, 95, 895-918.

Todorov, S. D., Wachsman, M., Tomé, E., Dousset, X., Destro, M. T., Dicks, L. M. T., \& Drider, D. (2010). Characterization of an antiviral pediocin-like bacteriocin produced by Enterococcus faecium. Food Microbiology, 27, 869-879.

Tosukhowong, A., Zendo, T., Visessanguan, W., Roytrakul, S., Pumpuang, L., \& Jaresithikunchai, J. (2012). Garvieacin Q a novel class II bacteriocin from Lactococcus garvieae BCC 43578. Applied and Environmental Microbiology, 78, 1619-1623.

Vasyliuk, O. M., Kovalenko, N. K., \& Garmasheva, I. L. (2014). Antagonistychni vlastyvosti shtamiv Lactobacillus plantarum, izolovanyh iz tradycijnyh fermentovanyh produktiv Ukrainy [Antagonistic properties of strains of Lactobacillus plantarum, isolated from traditional fermented products of Ukraine]. Mikrobiologichnyj Zhurnal, 76(3), 24-30 (in Ukrainian).

Vendrell, D., Balcázar, J. L., Ruiz-Zarzuela, I., de Blas, I., Gironés, O., \& Múzquiz, J. L. (2006). Lactococcus garvieae in fish: A review. Comparative Immunology, Microbiology and Infectious Diseases, 29, 177-198.

Wang, T., \& Liu, M. (2016). The effect of bacteriocins derived from lactic acid bacteria on growth and biofilm formation of clinical pathogenic strains. International Journal of Clinical and Experimental Medicine, 9(4), 7343-7348.

Yerlikaya, O., \& Akbulut, N. (2019). Potential use of probiotic Enterococcus faecium and Enterococcus durans strains in Izmir Tulum cheese as adjunct culture. Journal of Food Science and Technology, 56(4), 2175-2185.

Yukalo, V. G., \& Storozh, L. A. (2018). Isolation of $\kappa-C N-1 P$ and $\beta-C N-5 P$ fractions from native casein micelles. The Ukrainian Biochemical Journal, 90(4), 74-79 (in Ukrainian).

Zhang, F., Jiang, M., Wan, C., Chen, X., Chen, X., Tao, X., Shah, N. P., \& Wei, H. (2016). Screening probiotic strains for safety: Evaluation of virulence and antimicrobial susceptibility of enterococci from healthy Chinese infants. Journal of Dairy Science, 99, 4282-4290.

Zhang, J., Yang, Y., Yang, H., Bu, Y., Yi, H., Zhang, L., Han, X., \& Ai, L. (2018). Purification and partial characterization of bacteriocin Lac-B23, a novel bacteriocin production by Lactobacillus plantarum $\mathrm{J} 23$, isolated from chinese traditional fermented milk. Frontiers in Microbiology, 9, 2165. 